\title{
Effect of Alumina Content on the Mechanical Properties of Alumina Particle Dispersion Magnesium
}

\author{
Shigehiro Kawamori ${ }^{1}$, Kiyoshi Kuroda ${ }^{1}$, Yukio Kasuga ${ }^{1}$, Masahiro Yokouchi ${ }^{2}$, \\ Hiroshi Fujiwara ${ }^{3}$ and Kei Ameyama ${ }^{4}$ \\ ${ }^{1}$ Department of Intelligent Mechanical Systems, College of Engineering, Tamagawa University, Tokyo 194-8610, Japan \\ ${ }^{2}$ Kanagawa Industrial Technology Center, Ebina 243-0435, Japan \\ ${ }^{3}$ Ritsumeikan Global Innovation Research Organization, Ritsumeikan University, Kusatsu 525-8577, Japan \\ ${ }^{4}$ Department of Mechanical Engineering, College of Science and Engineering, Ritsumeikan University, Kusatsu 525-8577, Japan
}

To enhance the mechanical properties of magnesium $(\mathrm{Mg})$ alloys, powders of pure $\mathrm{Mg}\left(\mathrm{Al}_{2} \mathrm{O}_{3} / \mathrm{Mg}\right)$ dispersed with over 10 vol\% alumina $\left(\mathrm{Al}_{2} \mathrm{O}_{3}\right)$ particles were made by ball milling powder mixtures of pure $\mathrm{Mg}$ and $\mathrm{Al}_{2} \mathrm{O}_{3}$ particles with particle sizes of 0.3 and $1 \mu \mathrm{m}$. The effect of the $\mathrm{Al}_{2} \mathrm{O}_{3}$ content of hot-pressed discs formed from the $\mathrm{Al}_{2} \mathrm{O}_{3} / \mathrm{Mg}$ powders on the mechanical properties of the discs was investigated. The $\mathrm{Al}_{2} \mathrm{O}_{3}$ particles were found to be uniformly dispersed in the $\mathrm{Al}_{2} \mathrm{O}_{3} / \mathrm{Mg}$ discs. The hardness of the discs increased sharply at an $\mathrm{Al}_{2} \mathrm{O}_{3}$ content of $20 \mathrm{vol} \%$. This is considered to be because of the excellent interfacial bonding between $\mathrm{Mg}$ and $\mathrm{Al}_{2} \mathrm{O}_{3}$ when the $\mathrm{Al}_{2} \mathrm{O}_{3} / \mathrm{Mg}$ discs contain a sufficient amount of $\mathrm{Al}_{2} \mathrm{O}_{3}$ particles and have a sufficient interparticle distance. The maximum hardness of a $20 \mathrm{vol} \% \mathrm{Al}_{2} \mathrm{O}_{3} / \mathrm{Mg}_{\mathrm{g}}$ disc (with an $\mathrm{Al}_{2} \mathrm{O}_{3}$ particle size of $0.3 \mu \mathrm{m}$ ) was $220 \mathrm{HV}$, which is much higher than the hardness of $\mathrm{AZ} 91 \mathrm{Mg}$ alloys. The bending strength of the $\mathrm{Al}_{2} \mathrm{O}_{3} / \mathrm{Mg}$ discs increased from 0 to 10 vol\% $\mathrm{Al}_{2} \mathrm{O}_{3}$ and then decreased from $20 \mathrm{vol} \% \mathrm{Al}_{2} \mathrm{O}_{3}$. It is considered that the 0 and 10 vol\% discs have similar fracture deflections and that the $10 \mathrm{vol} \%$ discs with $\mathrm{Al}_{2} \mathrm{O}_{3}$ particles can withstand higher compression and tension forces than the 0 vol\% discs which do not contain any particles. The reason for the lower bending strength of the $20 \mathrm{vol} \% \mathrm{Al}_{2} \mathrm{O}_{3}$ disc is thought to be because it is harder and more brittle, making it easier for voids to form in the discs, and thus making it easier for cracks to propagate on the specimen surface. [doi:10.2320/matertrans.M2010060]

(Received February 18, 2010; Accepted July 9, 2010; Published August 25, 2010)

Keywords: alumina particle dispersion magnesium powder, attritor ball mill, hot pressing, microstructures, hardness, bending strength

\section{Introduction}

In recent years, advances in automotive lighting have led to an increase in the demand for magnesium $(\mathrm{Mg})$ alloys, which are lightweight substitutes for aluminum $(\mathrm{Al})$ alloys. However, Mg alloys generally have inferior mechanical properties to $\mathrm{Al}$ alloys.

One potential method to improve the mechanical properties of $\mathrm{Mg}$ alloys is to form composites of $\mathrm{Mg}$ alloys and ceramic particles and/or fibers. Recently, composites of pure $\mathrm{Mg}$ or $\mathrm{Mg}$ alloys with ceramic particles and/or fibers have been fabricated by casting and powder metallurgical processes. These composites have been widely studied.

The fabrication of composites of pure $\mathrm{Mg}$ reinforced by alumina $\left(\mathrm{Al}_{2} \mathrm{O}_{3}\right)$ particles by the powder metallurgical process has been studied. ${ }^{1-4)}$ In an attempt to improve the dispersion strengthening of $\mathrm{Mg}$ in $\mathrm{Al}_{2} \mathrm{O}_{3}$, instead of mixing pure $\mathrm{Mg}$ powder with several vol\% of $\mathrm{Al}_{2} \mathrm{O}_{3}$ nanoparticles, Unverricht et al. ${ }^{4)}$ ball milled the two powders to uniformly disperse $\mathrm{Al}_{2} \mathrm{O}_{3}$ particles in $\mathrm{Mg}$. When investigating the dispersion strengthening, an $\mathrm{Al}_{2} \mathrm{O}_{3}$ content of several vol\% is used.

However, little research has been conducted on uniform dispersions of over $10 \mathrm{vol} \% \mathrm{Al}_{2} \mathrm{O}_{3}$ particles in pure $\mathrm{Mg}$ powder produced by mechanical milling pure $\mathrm{Mg}$ and $\mathrm{Al}_{2} \mathrm{O}_{3}$ particles. The hardness and the wear resistance of a powder of over $10 \mathrm{vol} \% \mathrm{Al}_{2} \mathrm{O}_{3}$ particles uniformly dispersed in pure $\mathrm{Mg}$ $\left(\mathrm{Al}_{2} \mathrm{O}_{3} / \mathrm{Mg}\right)$ are expected to be higher than those of an $\mathrm{Al}_{2} \mathrm{O}_{3}$ dispersion strengthened powder, because the strength of $\mathrm{Al}_{2} \mathrm{O}_{3}$ particles will enhance that of the $\mathrm{Al}_{2} \mathrm{O}_{3} / \mathrm{Mg}$ powder.

The surface properties of pure $\mathrm{Mg}$ or $\mathrm{Mg}$ alloys are expected to be improved by bonding $\mathrm{Al}_{2} \mathrm{O}_{3} / \mathrm{Mg}$ to $\mathrm{Mg}$ substrates using processes such as plasma spraying or hot rolling. ${ }^{5)}$

Moreover, $\mathrm{Al}_{2} \mathrm{O}_{3} / \mathrm{Mg}$ powders can be used to fabricate sintered compacts that have superior mechanical properties by various pressure sintering processes such as hot pressing, hot isostatic pressing, spark plasma sintering and hot roll sintering. ${ }^{6)}$

We have made $\mathrm{Al}_{2} \mathrm{O}_{3} / \mathrm{Mg}$ powders by ball milling powder mixtures of pure $\mathrm{Mg}$ powder and $0-22.7 \mathrm{vol} \% \quad \mathrm{Al}_{2} \mathrm{O}_{3}$ particles with $\mathrm{Al}_{2} \mathrm{O}_{3}$ particle sizes of $1 \mu \mathrm{m}$. We then investigated the mechanical properties of hot-pressed discs obtained from these $\mathrm{Al}_{2} \mathrm{O}_{3} / \mathrm{Mg}$ powders and found that they have higher hardnesses than AZ91 Mg alloys. ${ }^{7)}$

In the present study, the effect of the $\mathrm{Al}_{2} \mathrm{O}_{3}$ content of the hot-pressed discs fabricated from over 10 vol\% $\mathrm{Al}_{2} \mathrm{O}_{3} / \mathrm{Mg}$ powders with $\mathrm{Al}_{2} \mathrm{O}_{3}$ particle sizes of 0.3 and $1 \mu \mathrm{m}$ on the mechanical properties of the discs was investigated.

\section{Experimental Procedures}

\subsection{Test powders}

Pure magnesium powder with a particle size of $180 \mu \mathrm{m}$, (Mg powder, Kojundo Chemical Laboratory Co. Ltd.; purity: 99.5\%) and $\alpha$-alumina particles with particle sizes of 0.3 and $1 \mu \mathrm{m}\left(\mathrm{Al}_{2} \mathrm{O}_{3}\right.$ particles, Kojundo Chemical Laboratory Co. Ltd.; purities: $99.99 \%$ and $99.9 \%$, respectively) were used as the starting materials.

\subsection{Trial process}

Figure 1 depicts the trial process for $\mathrm{Al}_{2} \mathrm{O}_{3}$ particle dispersion magnesium $\left(\mathrm{Al}_{2} \mathrm{O}_{3} / \mathrm{Mg}\right)$ discs. $\mathrm{Al}_{2} \mathrm{O}_{3} / \mathrm{Mg}$ pow- 


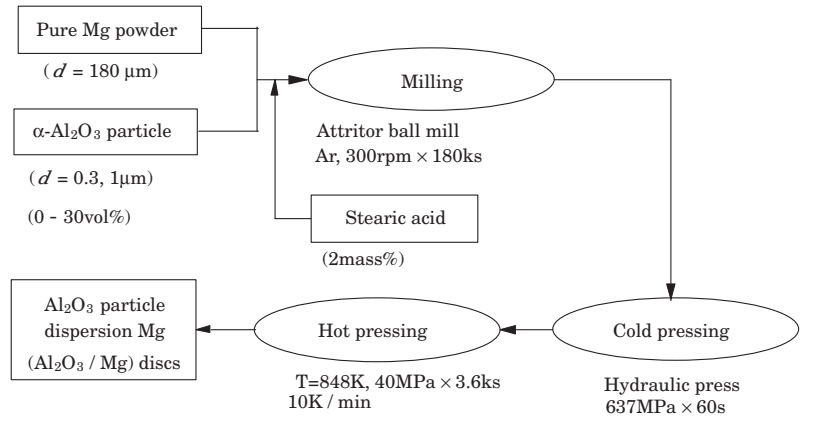

Fig. 1 Trial process for $\mathrm{Al}_{2} \mathrm{O}_{3}$ particle dispersion $\mathrm{Mg}$ discs.

ders were milled in an attritor ball mill. Powder mixtures of $200 \mathrm{~cm}^{3} \mathrm{Mg}$ and $0-30$ vol\% $\mathrm{Al}_{2} \mathrm{O}_{3}$ particles were fed into an $\mathrm{Al}_{2} \mathrm{O}_{3}$ container together with $3 \mathrm{dm}^{3} 5 \mathrm{~mm}$ diameter $\mathrm{Al}_{2} \mathrm{O}_{3}$ balls. Mixtures of $\mathrm{Al}_{2} \mathrm{O}_{3}$ particles with $\mathrm{Mg}$ powder with $\mathrm{Al}_{2} \mathrm{O}_{3}$ particle contents of $0,10,20$, and $30 \mathrm{vol} \%$ were produced.

The $\mathrm{Al}_{2} \mathrm{O}_{3}$ agitator arm was rotated at $300 \mathrm{rpm}$ for $180 \mathrm{ks}$ in an argon atmosphere to mill the mixed powders. 2 mass $\%$ stearic acid was added as a lubricant. The obtained $\mathrm{Al}_{2} \mathrm{O}_{3}$ / $\mathrm{Mg}$ powders were compacted into green discs using a hydraulic press at $637 \mathrm{MPa}$ for $60 \mathrm{~s}$. The green discs were hot compressed at $40 \mathrm{MPa}$ and $848 \mathrm{~K}$ for $3.6 \mathrm{ks}$ in a carbon sample holder with an argon atmosphere. The furnace was then cooled to room temperature and $\mathrm{Al}_{2} \mathrm{O}_{3} / \mathrm{Mg}$ discs were obtained.

\subsection{Evaluation}

The average particle sizes of the $\mathrm{Al}_{2} \mathrm{O}_{3} / \mathrm{Mg}$ powders were obtained by measuring the size distribution using a laser diffraction particle size analyzer (Sympatec GmbH, Helos \& Lodos). $\mathrm{Al}_{2} \mathrm{O}_{3} / \mathrm{Mg}$ discs with a disc thickness tolerance of $\pm 0.05 \mathrm{~mm}$ were finished by polishing with abrasive paper and buffing. Microstructural observations and qualitative analysis of the $\mathrm{Al}_{2} \mathrm{O}_{3} / \mathrm{Mg}$ powders and discs were performed using an optical microscope (Olympus Co. Ltd., STM5-UM), a field-emission scanning electron microscope (SEM; Hitachi Ltd., S-4300SE), an electron probe microanalyzer (EPMA, Jeol Ltd., JXA-8500F), and an X-ray diffractometer (Philips Co. Ltd., X'pert Pro MPD).

The disc densities were measured using a hydrometer. The relative density was obtained by dividing the measured density by the theoretical density:

$$
\rho_{\mathrm{R}}=\frac{\rho}{\rho_{0}} \times 100
$$

where $\rho_{\mathrm{R}}$ is the relative density, $\rho$ is the measured density of a disc, and $\rho_{0}$ is the theoretical density (e.g., Mg-10 vol\% $\mathrm{Al}_{2} \mathrm{O}_{3}$ has a theoretical density of $1.96 \times 10^{3} \mathrm{~kg} / \mathrm{m}^{3}$ ).

The hardness of the $\mathrm{Al}_{2} \mathrm{O}_{3} / \mathrm{Mg}$ discs were measured using a Vickers hardness tester at $49 \mathrm{~N}$ for $10 \mathrm{~s}$. Five values were measured for each of the three discs.

The $\mathrm{Al}_{2} \mathrm{O}_{3} / \mathrm{Mg}$ discs were machined to give plates with dimensions of $19.6 \mathrm{~mm}$ (length) $\times 5 \mathrm{~mm}$ (width) $\times 1.4 \mathrm{~mm}$ (thickness). After buffing both surfaces, the plates were used in bending tests. The bending strength was calculated using the following formula for a beam:

$$
\sigma_{\mathrm{F}}=\frac{3 P_{\max } L}{2 d t^{2}}
$$

where $\sigma_{\mathrm{F}}$ is the bending strength, $P_{\max }$ is the maximum load, $L$ is the distance between the support points, $d$ is the specimen width, and $t$ is the specimen thickness. Values were obtained for five to six discs. All discs failed at the center of span.

\section{Results and Discussion}

\subsection{Observations of $\mathrm{Al}_{2} \mathrm{O}_{3} / \mathrm{Mg}$ powders and discs 3.1.1 $\mathrm{Al}_{2} \mathrm{O}_{3} / \mathrm{Mg}$ powders}

Figure 2(a) and (b) respectively show SEM images of the surface and the cross-section of the $20 \mathrm{vol} \% \quad \mathrm{Al}_{2} \mathrm{O}_{3} / \mathrm{Mg}$ powder with an $\mathrm{Al}_{2} \mathrm{O}_{3}$ particle size of $1 \mu \mathrm{m}$. Figure 2(a) shows the size variation of the $\mathrm{Al}_{2} \mathrm{O}_{3} / \mathrm{Mg}$ powder. The average powder size was about $20 \mu \mathrm{m}$. The other powders exhibited similar morphologies and average sizes.

The recovery ratio of $\mathrm{Al}_{2} \mathrm{O}_{3} / \mathrm{Mg}$ powder extracted from the ball-mill decreased because the volume of powder solidification by milling increases with increasing $\mathrm{Al}_{2} \mathrm{O}_{3}$ content.

The average particle size of $\mathrm{Al}_{2} \mathrm{O}_{3} / \mathrm{Mg}$ powders is considered to remain approximately constant with increasing $\mathrm{Al}_{2} \mathrm{O}_{3}$ content, because although the $\mathrm{Al}_{2} \mathrm{O}_{3} / \mathrm{Mg}$ powders become finer with increasing $\mathrm{Al}_{2} \mathrm{O}_{3}$ content, they are more likely to agglutinate at higer $\mathrm{Al}_{2} \mathrm{O}_{3}$ contents.

Figure 2(c) is a high magnification image of Fig. 2(b). Elemental analysis for $\mathrm{Mg}, \mathrm{Al}$, and $\mathrm{O}$ using EPMA revealed that the gray regions in Fig. 2(c) are $\mathrm{Mg}$ and the fine white particles are $\mathrm{Al}_{2} \mathrm{O}_{3}$ particles. Figures 2(b) and (c) show that the $\mathrm{Al}_{2} \mathrm{O}_{3}$ particles are uniformly dispersed in the $\mathrm{Mg}$ powder. Similar tendencies were observed for the other $\mathrm{Al}_{2} \mathrm{O}_{3} / \mathrm{Mg}$ powders.

\subsection{2 $\quad \mathrm{Al}_{2} \mathrm{O}_{3} / \mathrm{Mg}$ discs}

Figure 3(a) shows a photograph of an $\mathrm{Al}_{2} \mathrm{O}_{3} / \mathrm{Mg}$ disc and Fig. 3(b)-(g) show SEM images of 10, 20, $30 \mathrm{vol} \% \mathrm{Al}_{2} \mathrm{O}_{3} /$ $\mathrm{Mg}$ discs. Figure 3(b), (d), and (f) show discs made from the $1 \mu \mathrm{m} \mathrm{Al}_{2} \mathrm{O}_{3}$ particles and Fig. 3(c), (e), and (g) show discs made from the $0.3 \mu \mathrm{m} \mathrm{Al}_{2} \mathrm{O}_{3}$ particles.

The discs had diameters in the range $20-21 \mathrm{~mm}$ and thicknesses in the range $1.5-2.0 \mathrm{~mm}$. $\mathrm{Al}_{2} \mathrm{O}_{3}$ particles are uniformly dispersed in the $\mathrm{Mg}$ in all the discs; voids are present in the $30 \mathrm{vol} \%$ discs.

Figure 4 shows the $\mathrm{Al}_{2} \mathrm{O}_{3}$ particle amount per $100 \mu \mathrm{m}^{2}$ and the interparticle distance as functions of $\mathrm{Al}_{2} \mathrm{O}_{3}$ content; these values were measured from the SEM images in Fig. 3(b)-(g) and other SEM images. The $\mathrm{Al}_{2} \mathrm{O}_{3}$ particle amount increased and the interparticle distance decreased with increasing $\mathrm{Al}_{2} \mathrm{O}_{3}$ content. The $0.3 \mu \mathrm{m} \mathrm{Al}_{2} \mathrm{O}_{3}$ particles have a higher particle density and a smaller interparticle distance than the $1.0 \mu \mathrm{m} \mathrm{Al}_{2} \mathrm{O}_{3}$ particles.

The measured $\mathrm{Al}_{2} \mathrm{O}_{3}$ particle amount is much higher than the calculated particle densities. For all $\mathrm{Al}_{2} \mathrm{O}_{3}$ contents, the $\mathrm{Al}_{2} \mathrm{O}_{3}$ particle sizes determined from the measured $\mathrm{Al}_{2} \mathrm{O}_{3}$ particle amount was about 0.2 and $0.3 \mu \mathrm{m}$ for particle sizes of 0.3 and $1.0 \mu \mathrm{m}$, respectively. These measured values are almost the same as the median size of $100 \mathrm{Al}_{2} \mathrm{O}_{3}$ particles in SEM images. The particles sizes used in this study ( 0.3 and 

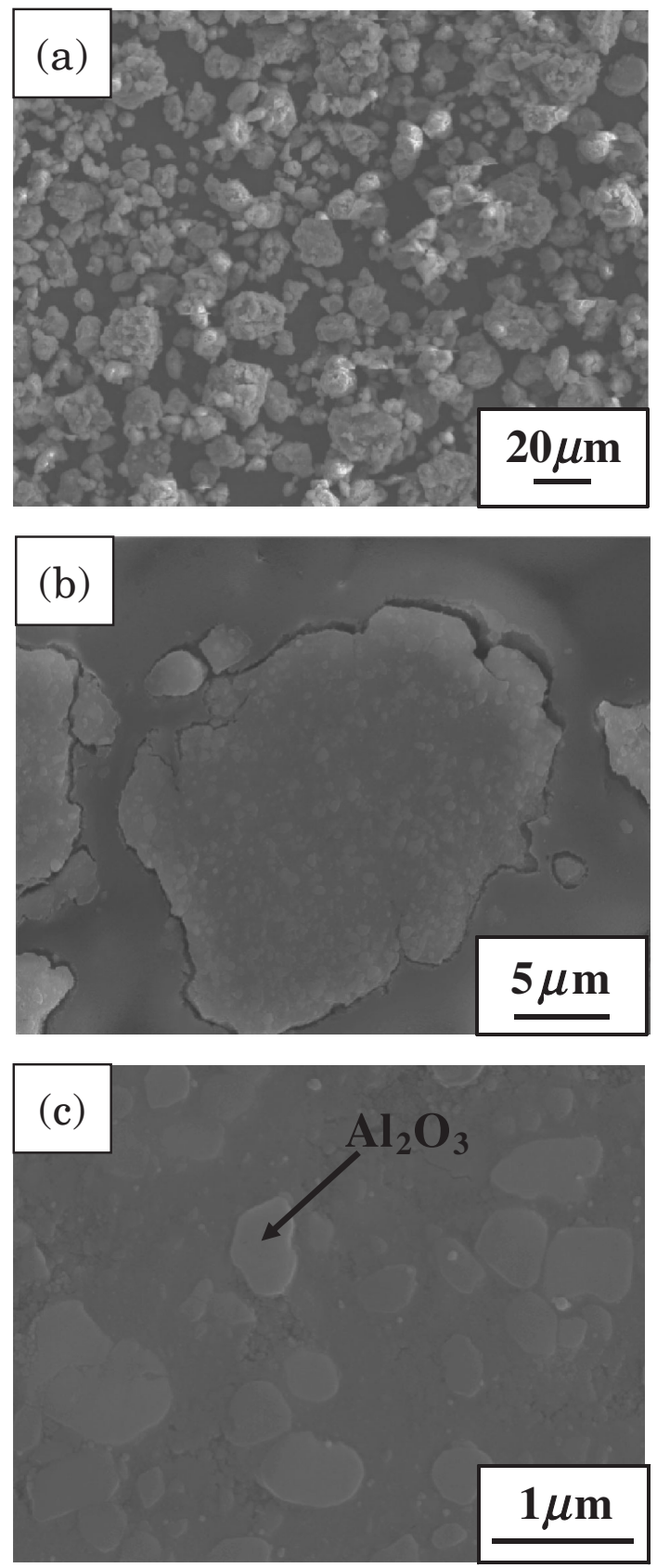

Fig. 2 SEM images of (a) the surface and (b) the cross-section of 20 vol\% $\mathrm{Al}_{2} \mathrm{O}_{3} / \mathrm{Mg}$ powder. (c) High-magnification image of (b).

$1.0 \mu \mathrm{m})$ represent the median sizes obtained by measuring size distributions by laser diffractometry. Even although different methods were used to measure the particle size, the $\mathrm{Al}_{2} \mathrm{O}_{3}$ particles in the $\mathrm{Al}_{2} \mathrm{O}_{3} / \mathrm{Mg}$ powders and discs are considered to have become finer than the original $\mathrm{Al}_{2} \mathrm{O}_{3}$ particles.

\subsection{Properties of $\mathrm{Al}_{2} \mathrm{O}_{3} / \mathrm{Mg}$ discs 3.2.1 Density}

Figure 5 shows the effect of $\mathrm{Al}_{2} \mathrm{O}_{3}$ content on the relative density of the $\mathrm{Al}_{2} \mathrm{O}_{3} / \mathrm{Mg}$ discs. The relative density of the 0 $20 \mathrm{vol} \% \mathrm{Al}_{2} \mathrm{O}_{3} / \mathrm{Mg}$ discs exceeds $100 \%$. This is assumed to be due to the formation of $\mathrm{MgO}$ by oxidation of the $\mathrm{Mg}$ powder as a result of exposure to air when ball milling the
$\mathrm{Al}_{2} \mathrm{O}_{3} / \mathrm{Mg}$ powders with active surfaces and of vaporization of stearic acid when heating the green compacts. Additionally, the solid-state reaction of $\mathrm{Mg}$ and $\mathrm{Al}_{2} \mathrm{O}_{3}$ particles is also considered to have an effect.

SEM observations of the $0-20$ vol\% discs reveal that the discs do not contain significant amounts of microscopic pores. The discs are thus considered to have been fully densified.

The relative density of the $30 \mathrm{vol} \%$ discs is less than $100 \%$. This is assumed to be due to their lower sinterabilities because of their lower workabilities as a result of their higher $\mathrm{Al}_{2} \mathrm{O}_{3}$ contents.

\subsubsection{Hardness}

Figure 6 shows the effect of $\mathrm{Al}_{2} \mathrm{O}_{3}$ content on the Vickers hardness of the $\mathrm{Al}_{2} \mathrm{O}_{3} / \mathrm{Mg}$ discs. The Vickers hardness of AZ91 alloys are also shown for comparison (these values were obtained by converting from the Brinell hardness numbers given in Ref. 8)).

For both $\mathrm{Al}_{2} \mathrm{O}_{3}$ particle sizes, the hardness of the $\mathrm{Al}_{2} \mathrm{O}_{3}$ / $\mathrm{Mg}$ discs decreased slightly when the $\mathrm{Al}_{2} \mathrm{O}_{3}$ content increased from 0 to $10 \mathrm{vol} \%$, increased sharply at $20 \mathrm{vol} \%$, and decreased at $30 \mathrm{vol} \%$. The discs containing the $0.3 \mu \mathrm{m} \mathrm{Al}_{2} \mathrm{O}_{3}$ particles had higher hardness than those containing the $1.0 \mu \mathrm{m} \mathrm{Al}_{2} \mathrm{O}_{3}$ particles. The maximum hardness of the $20 \mathrm{vol} \% \mathrm{Al}_{2} \mathrm{O}_{3} / \mathrm{Mg}$ discs is $220 \mathrm{HV}$, which is much higher than those of the AZ91 Mg alloys (indicated by the diagonal line in Fig. 6).

The following possible causes for the sharp increase in the hardness in the $20 \mathrm{vol} \% \mathrm{Al}_{2} \mathrm{O}_{3} / \mathrm{Mg}$ discs are discussed below:

(1) $\mathrm{Al}_{2} \mathrm{O}_{3}$ particle dispersion strengthening

(2) Inhibition of $\mathrm{Mg}$ grain growth

(3) Solid-state reaction of $\mathrm{Mg}$ with $\mathrm{Al}_{2} \mathrm{O}_{3}$ particles

(4) Interfacial bonding between $\mathrm{Mg}$ and $\mathrm{Al}_{2} \mathrm{O}_{3}$ particles

\section{(1) $\mathrm{Al}_{2} \mathrm{O}_{3}$ particle dispersion strengthening}

To consider the effect of $\mathrm{Al}_{2} \mathrm{O}_{3}$ particle dispersion strengthening, the stress necessary to pass dislocations between dispersed particles (known as "Orowan stress") was investigated.

The Orowan stress $\tau_{\mathrm{o}}$ is given by:

$$
\tau_{\mathrm{o}}=\frac{1.6 T}{\bar{l} b}
$$

where $T$ is line tension of dislocation, $\bar{l}$ is the average $\mathrm{Al}_{2} \mathrm{O}_{3}$ particle spacing, and $b$ is Burgers vector.

$T / b$ is assumed to be constant. The ratio of the Orowan stress of the 20 and $10 \mathrm{vol} \% \mathrm{Al}_{2} \mathrm{O}_{3} / \mathrm{Mg}$ discs were obtained from the average $\mathrm{Al}_{2} \mathrm{O}_{3}$ particle spacing for particle sizes of 0.3 and $1 \mu \mathrm{m}$ (see Fig. 4). The ratios were 1.1 and 1.4 for $\mathrm{Al}_{2} \mathrm{O}_{3}$ particle sizes of 0.3 and $1 \mu \mathrm{m}$, respectively. The Orowan stress increaseed little with increasing $\mathrm{Al}_{2} \mathrm{O}_{3}$ content.

In contrast, the ratio of the Vickers hardnesses of discs with $\mathrm{Al}_{2} \mathrm{O}_{3}$ contents of 20 and $10 \mathrm{vol} \%$ are 3.6 and 3.0 for $\mathrm{Al}_{2} \mathrm{O}_{3}$ particle sizes of 0.3 and $1 \mu \mathrm{m}$; these ratios are greater than the Orowan stress ratio.

Therefore, $\mathrm{Al}_{2} \mathrm{O}_{3}$ particle dispersion strengthening is considered to have very little effect because there almost no correlation between the Vickers hardness and the Orowan stress. 

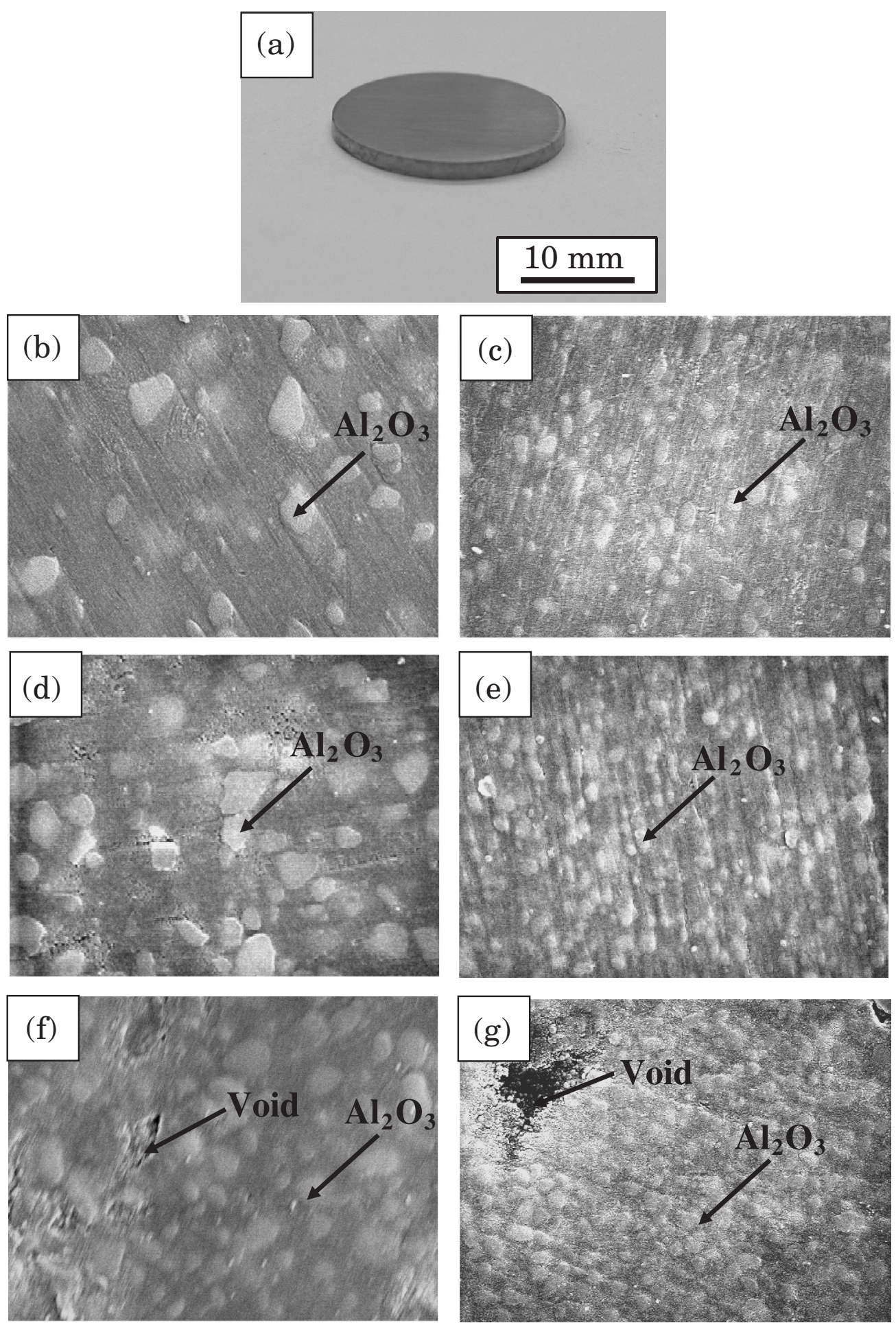

$1 \mu \mathrm{m}$

Fig. 3 (a) Appearance of $\mathrm{Al}_{2} \mathrm{O}_{3} / \mathrm{Mg}$ disc. SEM images of $10 \mathrm{vol} \% \mathrm{Al}_{2} \mathrm{O}_{3} / \mathrm{Mg}$ discs with $\mathrm{Al}_{2} \mathrm{O}_{3}$ particle sizes of (b) $1 \mu \mathrm{m}$ and (c) $0.3 \mu \mathrm{m}$, 20 vol $\% \mathrm{Al}_{2} \mathrm{O}_{3} / \mathrm{Mg}$ discs with $\mathrm{Al}_{2} \mathrm{O}_{3}$ particle sizes of (d) $1 \mu \mathrm{m}$ and (e) $0.3 \mu \mathrm{m}$ and 30 vol\% $\mathrm{Al}_{2} \mathrm{O}_{3} / \mathrm{Mg}$ discs with $\mathrm{Al}_{2} \mathrm{O}_{3}$ particle sizes of (f) $1 \mu \mathrm{m}$ and (g) $0.3 \mu \mathrm{m}$.

\section{(2) Inhibition of Mg grain growth}

$\mathrm{Mg}$ grain growth is considered to be inhibited with increasing $\mathrm{Al}_{2} \mathrm{O}_{3}$ particle content during hot pressing. Figure 7 shows optical microstructures of the 10 vol\% and 20 vol\% discs. The discs were electrolytically etched and the $\mathrm{Mg}$ grain sizes were measured. All the discs have Mg grain sizes in the range $5-8 \mu \mathrm{m}$. The 0 and $30 \mathrm{vol} \%$ discs have similar grain sizes.

$\mathrm{Al}_{2} \mathrm{O}_{3}$ particles are considered to be present in both the $\mathrm{Mg}$ grains and grain boundaries, because the $\mathrm{Al}_{2} \mathrm{O}_{3}$ interparticle distance is $0.15-0.3 \mu \mathrm{m}$ (see Fig. 4), and the $\mathrm{Al}_{2} \mathrm{O}_{3}$ particles are uniformly dispersed in Mg (Fig. 3(b)-(g)). 


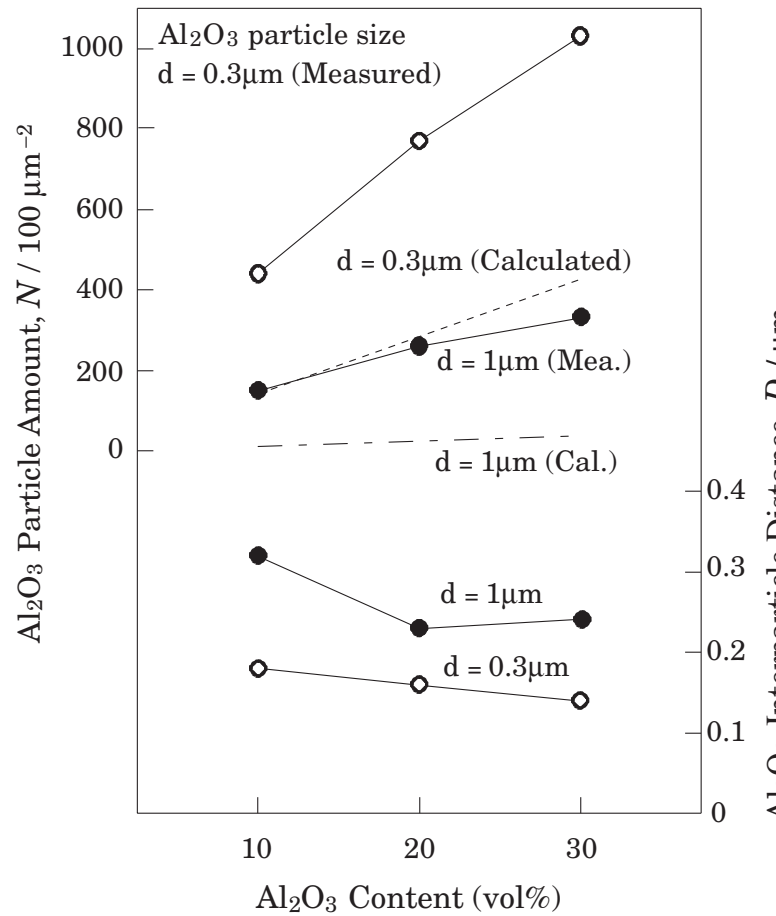

Fig. $4 \mathrm{Al}_{2} \mathrm{O}_{3}$ particle amount and interparticle distance as functions of $\mathrm{Al}_{2} \mathrm{O}_{3}$ content in $\mathrm{Al}_{2} \mathrm{O}_{3} / \mathrm{Mg}$ discs.

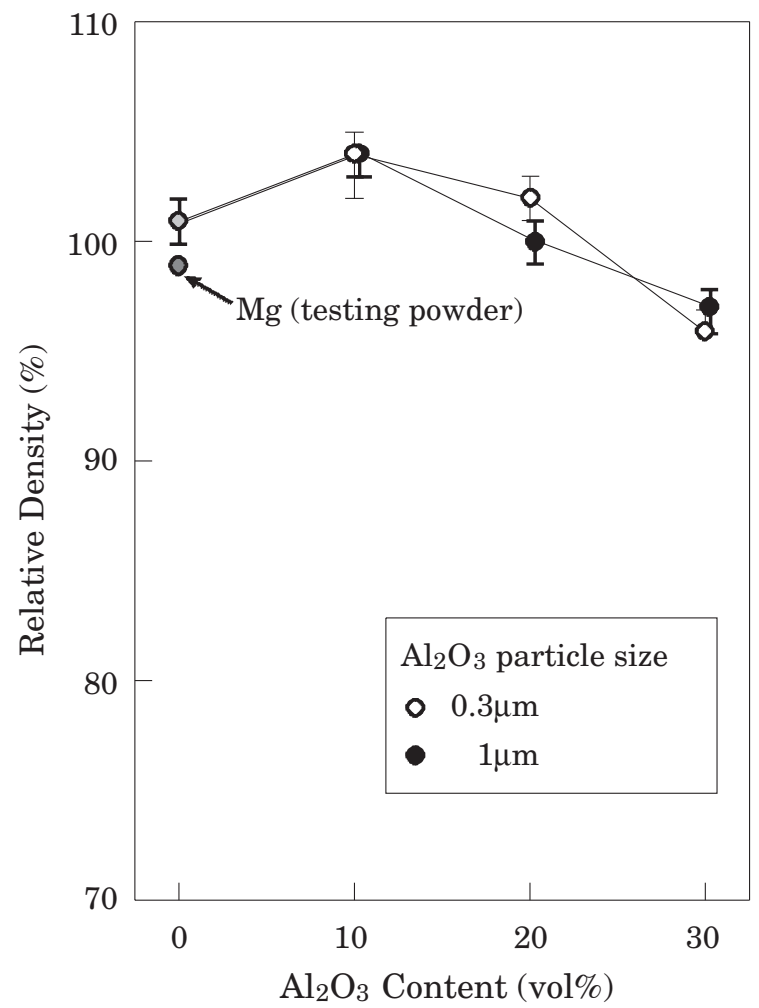

Fig. 5 Effect of $\mathrm{Al}_{2} \mathrm{O}_{3}$ content on the relative density of the $\mathrm{Al}_{2} \mathrm{O}_{3} / \mathrm{Mg}$ discs.

There is considered to be very little inhibition of $\mathrm{Mg}$ grain growth with increasing $\mathrm{Al}_{2} \mathrm{O}_{3}$ particle density, because grain growth is independent of the $\mathrm{Al}_{2} \mathrm{O}_{3}$ particle size and the $\mathrm{Al}_{2} \mathrm{O}_{3}$ content.

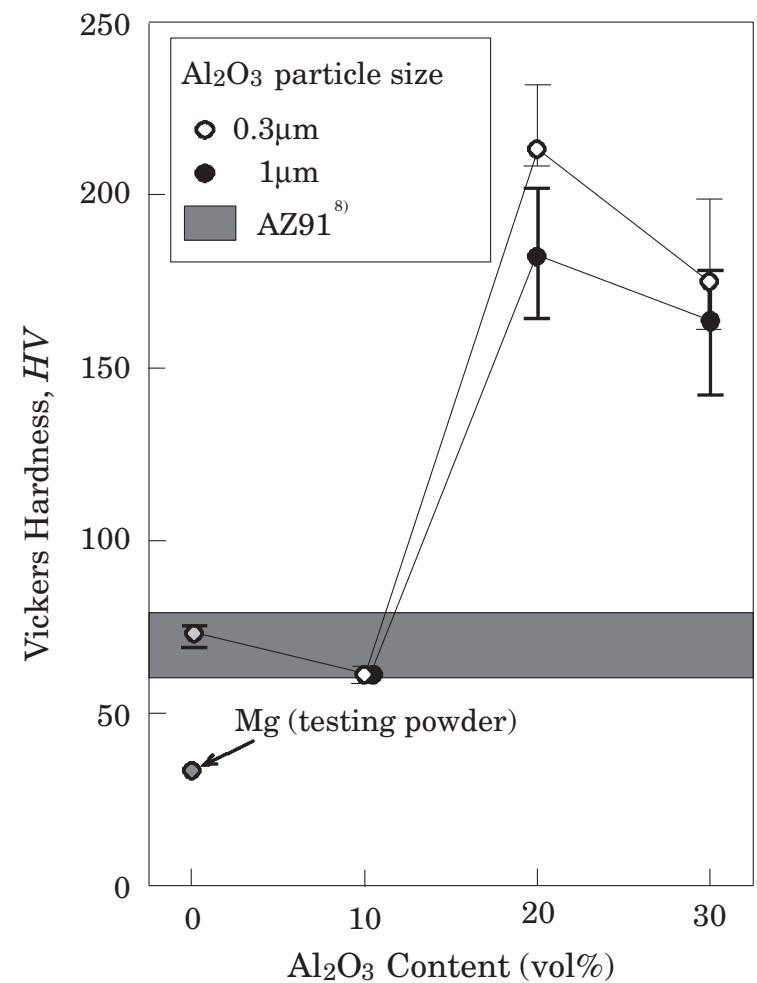

Fig. 6 Effect of $\mathrm{Al}_{2} \mathrm{O}_{3}$ content on the Vickers hardness of the $\mathrm{Al}_{2} \mathrm{O}_{3} / \mathrm{Mg}$ discs.

\section{(3) Solid-state reaction of $\mathrm{Mg}$ with $\mathrm{Al}_{2} \mathrm{O}_{3}$ particles}

The compound produced by the solid-state reaction of $\mathrm{Mg}$ with $\mathrm{Al}_{2} \mathrm{O}_{3}$ particle is considered to increase with increasing amount of $\mathrm{Al}_{2} \mathrm{O}_{3}$ particles. Figure 8 shows X-ray diffraction (XRD) results for $\mathrm{Al}_{2} \mathrm{O}_{3} / \mathrm{Mg}$ discs with different $\mathrm{Al}_{2} \mathrm{O}_{3}$ contents. As shown in Fig. 8, magnesium oxide $(\mathrm{MgO})$ is identified in all the discs, in addition to $\mathrm{Mg}$ and $\mathrm{Al}_{2} \mathrm{O}_{3}$. An $\mathrm{XRD}$ peak assigned to an $\mathrm{Al}-\mathrm{Mg}$ intermetallic compound $\left(\mathrm{Mg}_{17} \mathrm{Al}_{12}\right)$ is detected for the $20 \mathrm{vol} \%$ disc with an $\mathrm{Al}_{2} \mathrm{O}_{3}$ particle size of $0.3 \mu \mathrm{m}$ and for the $30 \mathrm{vol} \%$ discs, in addition to peaks due to $\mathrm{Mg}, \mathrm{Al}_{2} \mathrm{O}_{3}$, and $\mathrm{MgO}$.

Moreover, although $\mathrm{MgAl}_{2} \mathrm{O}_{4}$ is considered to be produced by the solid-state reaction of $\mathrm{MgO}$ and $\mathrm{Al}_{2} \mathrm{O}_{3},{ }^{9}$ it could not be identified in the XRD results of the present study.

Figure 9 shows $\mathrm{X}$-ray relative intensities for $\mathrm{Mg}$ (101) and $\mathrm{MgO}$ (220) of the $\mathrm{Al}_{2} \mathrm{O}_{3} / \mathrm{Mg}$ discs indicated by the arrows in Fig. 8. The relative intensity of the $\mathrm{Al}_{2} \mathrm{O}_{3} / \mathrm{Mg}$ discs increases with increasing $\mathrm{Al}_{2} \mathrm{O}_{3}$ content. The amount of $\mathrm{MgO}$ is considered to increase due to the solid-state reaction of $\mathrm{Mg}$ with $\mathrm{Al}_{2} \mathrm{O}_{3}$ particles progressing with increasing $\mathrm{Al}_{2} \mathrm{O}_{3}$ particle density.

The solid-state reaction of $\mathrm{Mg}$ with $\mathrm{Al}_{2} \mathrm{O}_{3}$ particles is as follows:

$$
35 \mathrm{Mg}+6 \mathrm{Al}_{2} \mathrm{O}_{3} \rightarrow 18 \mathrm{MgO}+\mathrm{Mg}_{17} \mathrm{Al}_{12} .
$$

$\mathrm{Al}$ is considered to be soluble in $\mathrm{Mg}$ due to the production of $\mathrm{MgO}$ by the reaction. Equation (4) shows that $\mathrm{Mg}_{17} \mathrm{Al}_{12}$ is produced when the $\mathrm{Mg}$ solid solution exceeds the solid solubility limit of $\mathrm{Al}$ to $\mathrm{Mg}$.

For the 20 vol\% discs, $\mathrm{Mg}_{17} \mathrm{Al}_{12}$ is detected only from the disc with an $\mathrm{Al}_{2} \mathrm{O}_{3}$ particle size of $0.3 \mu \mathrm{m}$. This is thought 

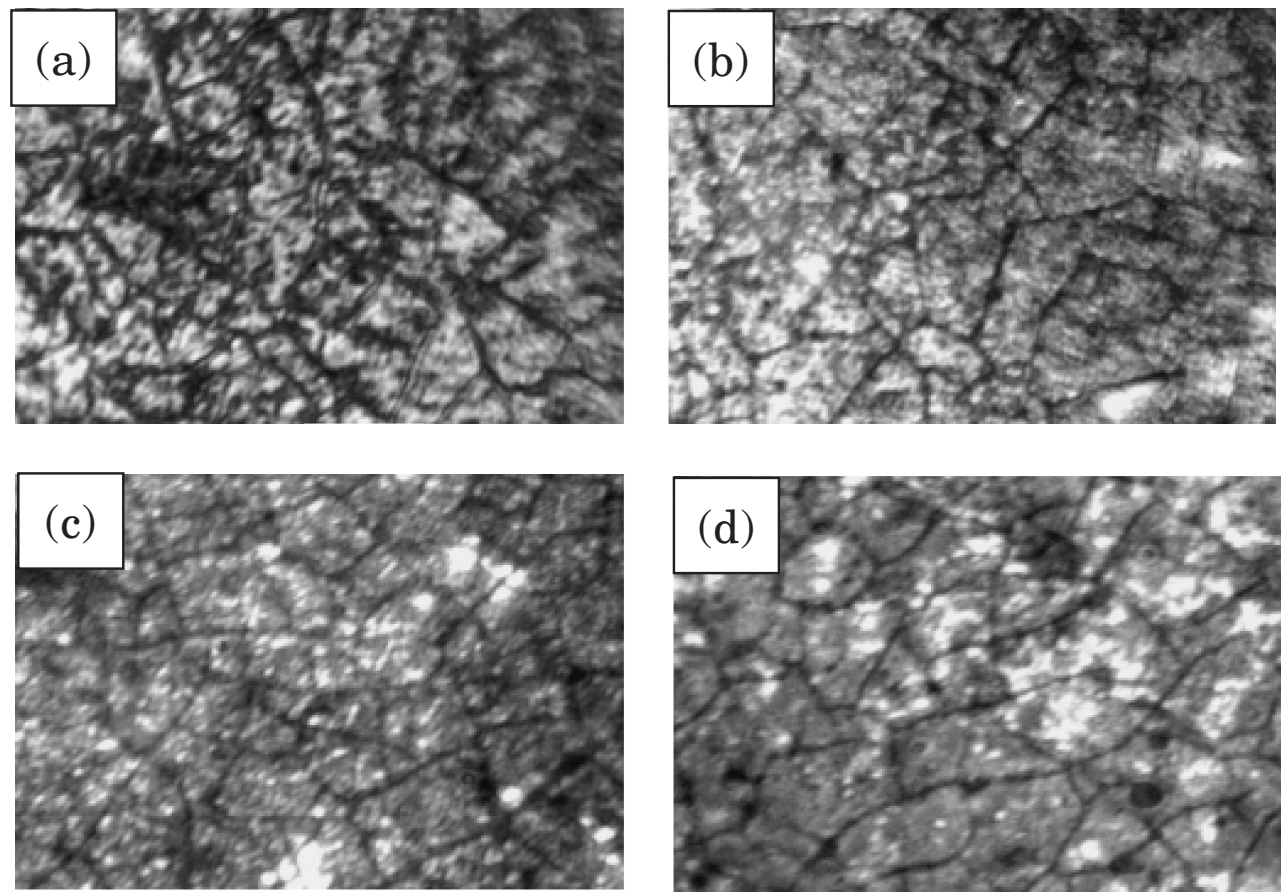

$10 \mu \mathrm{m}$

Fig. 7 Optical microstructures of $10 \mathrm{vol} \% \mathrm{Al}_{2} \mathrm{O}_{3} / \mathrm{Mg}$ discs with $\mathrm{Al}_{2} \mathrm{O}_{3}$ particle sizes of (a) $1 \mu \mathrm{m}$ and (b) $0.3 \mu \mathrm{m}$ and 20 vol $\% \mathrm{Al}_{2} \mathrm{O}_{3} / \mathrm{Mg}$ discs with $\mathrm{Al}_{2} \mathrm{O}_{3}$ particle sizes of (c) $1 \mu \mathrm{m}$ and (d) $0.3 \mu \mathrm{m}$.
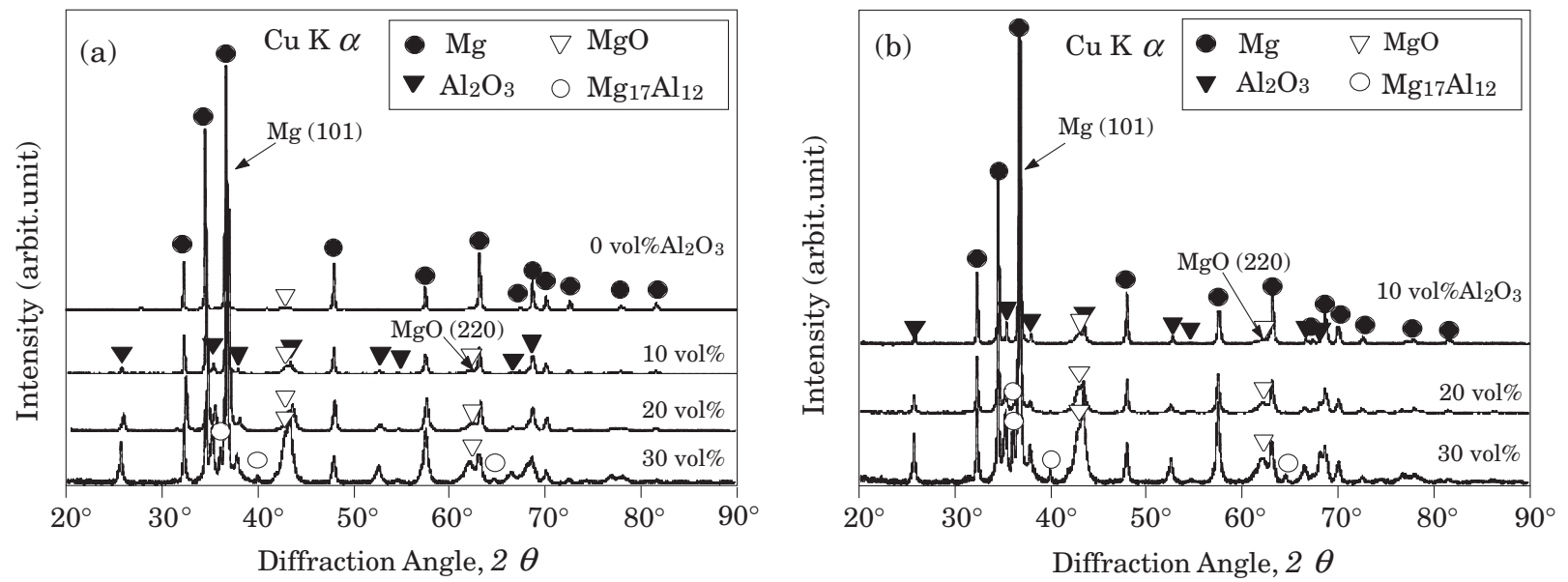

Fig. 8 XRD results for the $\mathrm{Al}_{2} \mathrm{O}_{3} / \mathrm{Mg}$ discs with $\mathrm{Al}_{2} \mathrm{O}_{3}$ particle sizes of (a) $1 \mu \mathrm{m}$ and (b) $0.3 \mu \mathrm{m}$.

to be because the finer $\mathrm{Al}_{2} \mathrm{O}_{3}$ particles react more readily with $\mathrm{Mg}$ due to their larger contact area with the $\mathrm{Al}_{2} \mathrm{O}_{3}$ particles.

The precipitation hardening of $\mathrm{Mg}_{17} \mathrm{Al}_{12}$ is thought to have little effect on the sharp increase in the hardness of the discs, because the XRD results reveal that only a small amount of $\mathrm{Mg}_{17} \mathrm{Al}_{12}$ is produced and because the deference of the hardness between pure $\mathrm{Mg}$ and precipitation-hardened AZ91 $\mathrm{Mg}$ alloy is not so great (the pure $\mathrm{Mg}$ (sand casting) and the AZ91 Mg alloy (sand casting and T6 temper) are $30 \mathrm{HB}^{10}$ ) and $70 \mathrm{HB},{ }^{8)}$ respectively). Moreover, both the $\mathrm{MgO}$ products and solid solution hardening of $\mathrm{Mg}$ with $\mathrm{Al}$ are thought to have little effect on the hardness since the $10 \mathrm{vol} \%$ discs have a similar hardness to the 0 vol\% discs.
(4) Interfacial bonding between $\mathrm{Mg}$ and $\mathrm{Al}_{2} \mathrm{O}_{3}$ particles

To investigate the interfacial bonding between $\mathrm{Mg}$ and $\mathrm{Al}_{2} \mathrm{O}_{3}$ particles, we observed indentations produced by the Vickers hardness test. Figure 10 shows the results. The edge of the plastically deformed indentation reveals that no abrasion occurs at the interface between the $\mathrm{Mg}$ and $\mathrm{Al}_{2} \mathrm{O}_{3}$ particles. Based on the results, the sharp increase in the hardness observed at $20 \mathrm{vol} \%$ is considered to be due to excellent interfacial bonding between $\mathrm{Mg}$ and $\mathrm{Al}_{2} \mathrm{O}_{3}$ particles, because terms of (1)-(3) are considered to have very little effect on the sharp increase.

Therefore, the sharp increase in the hardness is predicted to promote $\mathrm{Al}_{2} \mathrm{O}_{3}$ particle strengthening because of the hardness of the $\mathrm{Al}_{2} \mathrm{O}_{3}$ particles and the restraining effect of the 


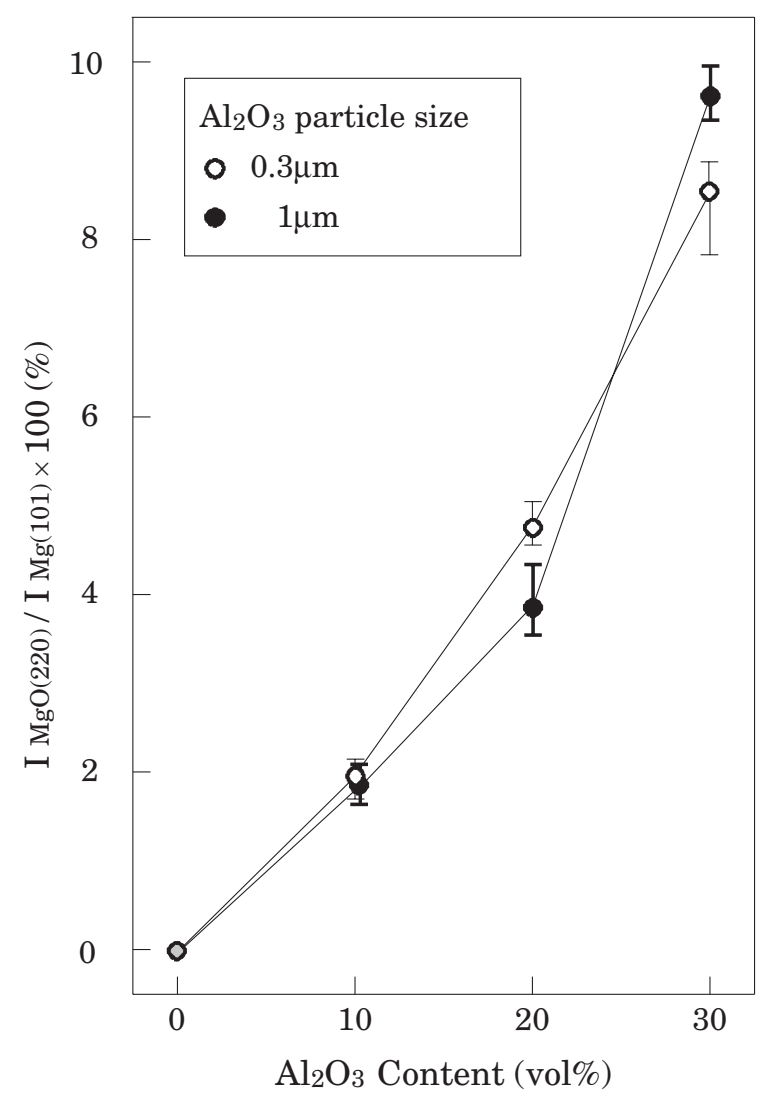

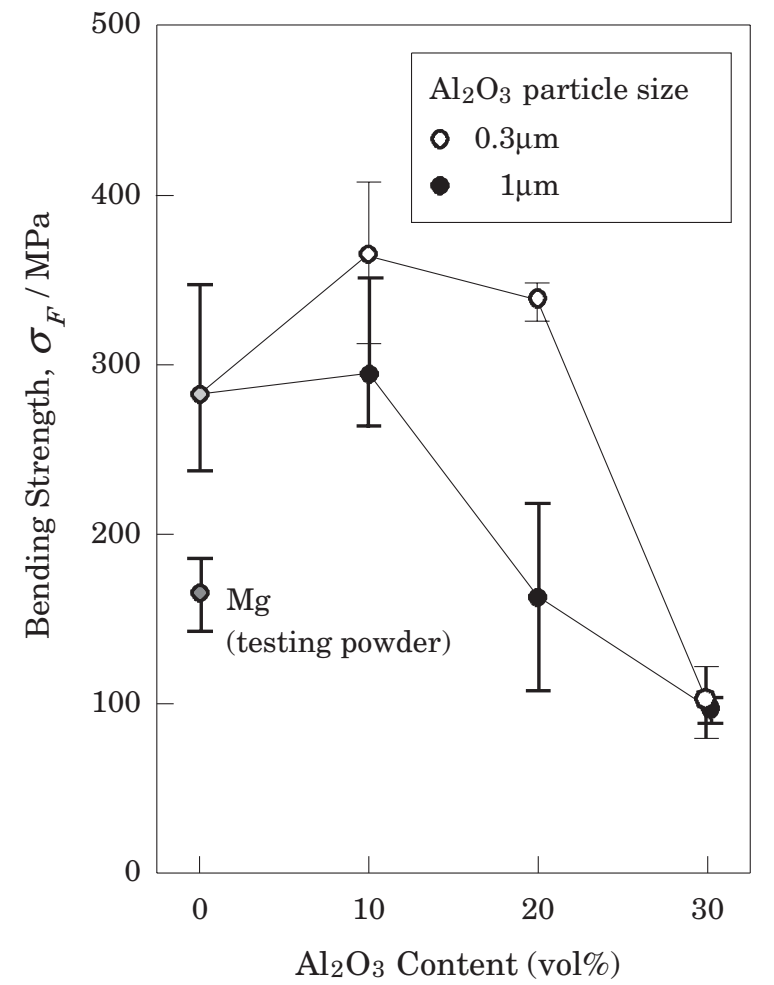

Fig. 11 Effect of $\mathrm{Al}_{2} \mathrm{O}_{3}$ content on the bending strength of $\mathrm{Al}_{2} \mathrm{O}_{3} / \mathrm{Mg}$ plates.

Fig. 9 Relative $\mathrm{Mg}$ to $\mathrm{MgO}$ X-ray peak intensities for the $\mathrm{Al}_{2} \mathrm{O}_{3} / \mathrm{Mg}$ discs.

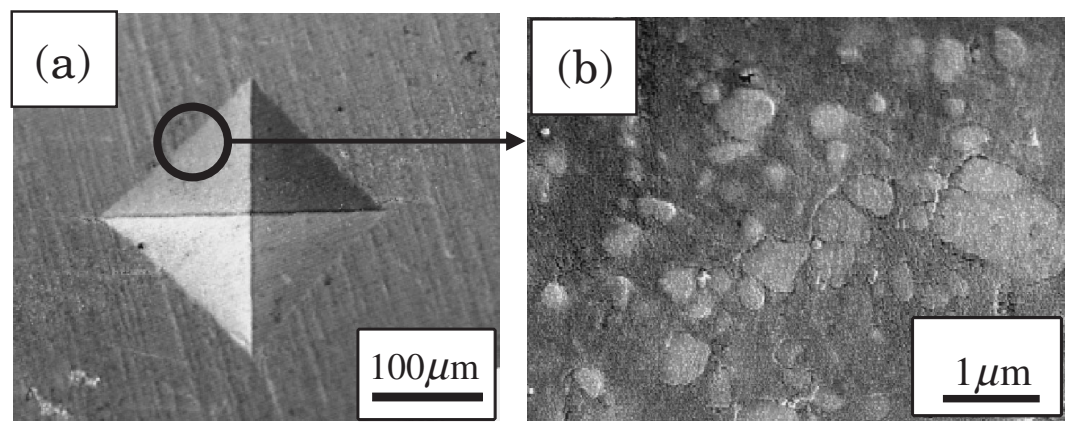

Fig. 10 (a) Image of Vickers hardness test indentation of 20 vol\% $\mathrm{Al}_{2} \mathrm{O}_{3} / \mathrm{Mg}$ disc. (b) High-magnification image of the area in the circle in (a) $\left(\mathrm{Al}_{2} \mathrm{O}_{3}\right.$ particle size is $\left.1 \mu \mathrm{m}\right)$.

$\mathrm{Mg}$ matrix as a result of the excellent interfacial bonding between $\mathrm{Mg}$ and $\mathrm{Al}_{2} \mathrm{O}_{3}$ particles. This will occur when the $\mathrm{Al}_{2} \mathrm{O}_{3} / \mathrm{Mg}$ discs contain a sufficient amount of $\mathrm{Al}_{2} \mathrm{O}_{3}$ particles with a sufficient interparticle distance.

The solid-state reaction of $\mathrm{Mg}$ with $\mathrm{Al}_{2} \mathrm{O}_{3}$ particles may contribute to the excellent interfacial bonding. However, detailed observations and analysis by transmission electron microscopy are necessary to confirm this conjecture.

\subsubsection{Bending strength}

Figure 11 shows the effect of $\mathrm{Al}_{2} \mathrm{O}_{3}$ content on the bending strength of $\mathrm{Al}_{2} \mathrm{O}_{3} / \mathrm{Mg}$ plates. For both $\mathrm{Al}_{2} \mathrm{O}_{3}$ particle sizes, the $10 \mathrm{vol} \%$ plates have a higher bending strength than the $0 \mathrm{vol} \%$ plates. It is considered that both plates have similar fracture deflections, and that the $10 \mathrm{vol} \%$ plates containing $\mathrm{Al}_{2} \mathrm{O}_{3}$ particles can withstand higher compression and tension forces than the 0 vol\% plate which does not contain any particles. The 20 vol $\%$ plates have lower bending strengths than the $10 \mathrm{vol} \%$ plates. This is thought to be because the plate becomes harder and more brittle, making it easier for voids to form in the discs. Based on these results, it considered that cracks generated on the specimen surface propagate more easily. This is supported by the observation of voids in the $30 \mathrm{vol} \%$ discs (see Fig. 3(f) and (g)) and indentation cracks were not observed after the Vickers hardness test for the 0 and $10 \mathrm{vol} \%$ discs, whereas they were observed for the 20 and 30 vol\% discs.

The discs containing $0.3 \mu \mathrm{m} \mathrm{Al}_{2} \mathrm{O}_{3}$ particles have higher bending strengths than those containing $1.0 \mu \mathrm{m} \mathrm{Al}_{2} \mathrm{O}_{3}$ particles.

Nobre et al. ${ }^{11)}$ have reported that AZ31 wrought magnesium alloys have a four-point bending strength of 200$220 \mathrm{MPa}$ for a compressive strain of $2.5 \%$. Although it is 
not possible to directly compare these results with those obtained in the present study since the test pieces have different shapes and different bending test methods were used, these bending strengths are similar to those of the 0-20 vol\% discs.

\section{Conclusions}

To enhance the mechanical properties of $\mathrm{Mg}$ alloys, over $10 \mathrm{vol} \% \mathrm{Al}_{2} \mathrm{O}_{3} / \mathrm{Mg}$ powders were formed by ball milling powder mixtures of pure $\mathrm{Mg}$ and $\mathrm{Al}_{2} \mathrm{O}_{3}$ particles with particle sizes of 0.3 and $1 \mu \mathrm{m}$. The effect of the $\mathrm{Al}_{2} \mathrm{O}_{3}$ content of hot-pressed discs formed from the $\mathrm{Al}_{2} \mathrm{O}_{3} / \mathrm{Mg}$ powders on the mechanical properties of the discs was investigated. The following results are obtained.

(1) For both $\mathrm{Al}_{2} \mathrm{O}_{3}$ particle sizes, the effect of $\mathrm{Al}_{2} \mathrm{O}_{3}$ content on both the hardness and the bending strength of the $\mathrm{Al}_{2} \mathrm{O}_{3} / \mathrm{Mg}$ discs exhibited similar tendencies.

(2) $\mathrm{The} \mathrm{Al}_{2} \mathrm{O}_{3} / \mathrm{Mg}$ discs containing $0.3 \mu \mathrm{m} \mathrm{Al}_{2} \mathrm{O}_{3}$ particles had higher hardness and bending strength than those containing $1 \mu \mathrm{m} \mathrm{Al}_{2} \mathrm{O}_{3}$ particles.

(3) The hardness of the $\mathrm{Al}_{2} \mathrm{O}_{3} / \mathrm{Mg}$ discs increased sharply when the $\mathrm{Al}_{2} \mathrm{O}_{3}$ content increased from 10 to $20 \mathrm{vol} \%$. It subsequently decreased at $30 \mathrm{vol} \%$.

(4) The reason for this sharp increase in hardness at an $\mathrm{Al}_{2} \mathrm{O}_{3}$ content of $20 \mathrm{vol} \%$ is thought to be due to $\mathrm{Al}_{2} \mathrm{O}_{3}$ particle strengthening as a result of the excellent interfacial bonding between $\mathrm{Mg}$ and $\mathrm{Al}_{2} \mathrm{O}_{3}$ particles. This will occur when the $\mathrm{Al}_{2} \mathrm{O}_{3} / \mathrm{Mg}$ discs contain a sufficient amount of $\mathrm{Al}_{2} \mathrm{O}_{3}$ particles and have a sufficient interparticle distance.
(5) The bending strength of the $\mathrm{Al}_{2} \mathrm{O}_{3} / \mathrm{Mg}$ plates increased when the $\mathrm{Al}_{2} \mathrm{O}_{3}$ content was increased from 0 to $10 \mathrm{vol} \%$ and it subsequently decreased at $20 \mathrm{vol} \%$.

(6) The 10 vol\% $\mathrm{Al}_{2} \mathrm{O}_{3} / \mathrm{Mg}$ plates have a higher bending strength than the $0 \mathrm{vol} \%$ plates. It is considered that both the 0 and $10 \mathrm{vol} \%$ plates have similar fracture deflections and that the $10 \mathrm{vol} \%$ plates with $\mathrm{Al}_{2} \mathrm{O}_{3}$ particles can withstand higher compression and tension forces than the $0 \mathrm{vol} \%$ plates which do not contain any particles.

\section{REFERENCES}

1) S. F. Hassan and M. Gupta: Mater. Sci. Eng. A 392 (2005) 163-168.

2) S. F. Hassan and M. Gupta: J. Metastable Nanocrystalline Mater. 23 (2005) 151-154.

3) X. L. Zhong and M. Gupta: J. Metastable Nanocrystalline Mater. 23 (2005) 171-174.

4) R. Unverricht, V. Peitz, W. Riehemann and H. Ferkel: Proc. Conf. on Magnesium Alloys and Their Applications, Deutsche, (Gesellschaft fur Materialkunde, 1998) pp. 327-332.

5) H. Oginuma and E. Yuasa: J. Jpn. Soc. Powder Powder Metall. 52 (2005) 35-40.

6) H. Fujiwara, M. Nakatani, Y. Iwahashi and K. Ameyama: Adv. Mater. Res. 26-28 (2007) 421-424.

7) S. Kawamori and T. Machida: Mater. Trans. 48 (2007) 373-379.

8) S. Housh, et al:: ASM Handbook Volume 2, (ASM international, 1990) p. 497.

9) S. Ikeno, K. Matsuda, T. Matsuki, T. Suzuki, N. Endo, T. Kawabata and Y. Uetani: J. Mater. Sci. 42 (2007) 5680-5685.

10) M. M. Avedesian and H. Baker: ASM Specialty Handbook, Magnesium and Magnesium Alloys, (ASM international, 1999) p. 10.

11) J. P. Nobre, U. Noster, M. Kornmeier, A. M. Dias and B. Scholtes: Key Eng. Mater. 230-232 (2002) 267-270. 